\title{
Pendampingan Laporan Kinerja Dan Penyusunan Rapat Anggota Tahunan (RAT) Koperasi Tani Makmur Desa Tejo Kecamatan Mojoagung
}

\author{
Omi Pramiana \\ omi_pramiana@yahoo.com \\ STIE PGRI Dewantara Jombang
}

\begin{abstract}
Abstrak
Kegiatan pengabdian masyarakat yang dilakukan di Koperasi Tani Desa Tejo adalah pendampingan laporan kinerja serta manajemen operasional penyaluran kredit. Permasalahan yang terjadi adalah laporan keuangan Koperasi Tani desa Tejo masih dirasa kurang khususnya operasionalnya dimana banyak terjadi kredit macet. Anggota yang meminjam modal pada Koperasi Tani Makmur desa Tejo tidak memiliki kesadaran untuk mengembalikan modal yang dipinjam dikarenaka tidak adanya penahanan barang atau harta sebagai jaminan. Laporan tahunan Koperasi Tani Makmur desa Tejo masih banyak yang belum diperbaiki seperti daftar inventaris yang belum di up date. Rasio keuangan menunjukkan kinerja Koperasi Tani Makmur desa Tejo sangat baik namun pada kenyataan banyak terjadi kredit macet hal ini disebabkan banyak modal yang masih mengendap pada kas sehingga kegiatan koperasi dirasa kurang produktif. Permasalahan diselesaikan dengan memberikan arahan dan materi akan pembuatan laporan keuangan serta manajemen operasional penyaluran kredit pada kepala desa, ketua, sekretaris dan bendahara.
\end{abstract}

Kata kunci: Pendampingan, laporan keuangan, manajemen operasional, koperasi tani

\begin{abstract}
Community service activities undertaken at Tejo Village Farmer Cooperative are the accompaniment of performance report and operational management of credit distribution. Problems that occur is the financial report Tejo Village Farm Cooperatives is still considered less particularly operational where there is a lot of bad credit. Members who borrow capital from Tejo Tani Makmur Cooperative do not have the awareness to return the borrowed capital due to the absence of custody of goods or assets as collateral. The annual report of Tejo Tani Makmur Cooperative is still largely unaddressed as inventory list is not yet up to date. The financial ratio shows the performance of Tani Makmur Cooperative Tejo village is very good but in reality many bad loans are caused by a lot of capital that still settles on cash so that cooperative activities are considered less productive. Problems solved by providing direction and materials for financial reporting and operational management of credit distribution to village head, chairman, secretary and treasurer
\end{abstract}

Keywords: Assistance, financial report, operational management, farmer cooperative

\section{A. Pendahuluan}

\section{Latar Belakang}

Koperasi berkembang menjadi organisasi bisnis yang dimiliki dan dioperasikan oleh orang-seorang demi kepentingan bersama. Koperasi melandaskan kegiatan berdasarkan prinsip gerakan ekonomi rakyat Koperasi di Indonesia didefinisikan sebagai badan usaha yang beranggotakan orang-seorang atau badan hukum koperasi dengan melandaskan kegiatannya berdasarkan prinsip-prinsip koperasi sekaligus sebagai gerakan yang berdasarkan asas kekeluargaan. ekonomi rakyat yang berdasar atas asas kekeluargaan. Di Indonesia, prinsip koperasi telah dicantumkan dalam UU No. 12 Tahun 1967, UU No. 25 Tahun 1992 dan diperbaharui dalam UU No. 17 Tahun 2012.

Koperasi adalah suatu gerakan otomatis untuk membela diri dari suatu kelompok masyarakat terhadap tekanan-tekanan hidup yang dilakukan oleh kelompok lain dalam 
masyarakat, baik yang berupa dominasi sosial maupun berupa eksploitasi ekonomi, sehingga menimbulkan rasa tidak aman bagi kehidupan mereka (Hendrojogi, 2012).

Koperasi merupakan gerakan ekonomi rakyat yang bertujuan untuk meningkatkan kesejahteraan masyarakat dengan melandaskan kegiataannya pada prinsip-prinsip Koperasi. Sebagai gerakan, koperasi menjunjung tinggi nilai-nilai kebersamaan dan kerja sama antar anggotanya yang sangat diperlukan untuk mewujudkan tujuan utamanya, yaitu meningkatkan kesejahteraan para anggotanya dan kemakmuran masyarakat (Mahri, 2014).

Sesuai dengan pasal 33 ayat 1 Undang Undang Dasar 1945, bahwa koperasi adalah merupakan salah satu pelaku ekonomi yang disusun dan dijalankan sebagai usaha bersama dari anggota dan untuk kesejahteraan seluruh anggota. Untuk mengembangkan usaha agribisnis skala kecil perlu dibentuk koperasi, tanpa koperasi tidak mungkin agribisnis kecil dapat berkembang. Lewat koperasi masyarakat pedesaan dapat belajar berbagai hal tidak hanya belajar bertani, berternak, dan berkebun tetapi dapat belajar pemasaran, manajemen, dan administrasi keuangan. Menurut UU No. 25/1992 Pasal 4 fungsi koperasi adalah sebagai berikut:

1. Membangun dan mengembangkan potensi dan kemampuan ekonomi anggota pada khususnya dan masyarakat pada umumnya untuk meningkatkan kesejahteraan ekonomi dan sosialnya.

2. Berperan serta secara aktif dalam upaya mempertinggi kualitas kehidupan manusia dan masyarakat.

3. Memperkokoh perekonomian rakyat sebagai dasar kekuatan dan ketahanan perekonomian nasional dengan koperasi sebagai sokogurunya.

4. Berusaha untuk mewujudkan dan mengembangkan perekonomian nasional yang merupakan usaha bersama berdasar atas azas kekeluargaan dan demokrasi ekonomi.

Salah satu jenis koperasi menurut PP No. 60/1959 adalah koperasi pertanian dimana merupakan koperasi yang kegiatannya khusus melayani dan menyediakan pupuk, obat pemberantas hama tanaman, benih, alat pertanian, dan memberi penyuluhan teknis pertanian.

\section{Profil Mitra}

Koperasi Tani Makmur terletak di Desa Tejo Kecamatan Mojoagung, dimana letak desa dengan Batas wilayah Sebelah Utara Desa Palrejo, Sebelah Selatan Desa Sukomulyo, Sebelah Timur Desa Gambiran dan Sebelah Barat Desa Sawahan. Koperasi Tani Makmur yang bergerak dalam unit simpan pinjam, diperlukan modal yang cukup dengan pengelolaan yang baik. Dimana sebagian modal diedarkan sebagai pinjaman untuk anggota dan calon anggota, sehingga modal koperasi bisa diolah dengan baik. Pengolahan modal usaha pada perusahaan dapat diwakilkan dengan rentabilitas perusahaan. Rentabilitas dapat digunakan sebagai ukuran untuk mengetahui seberapa besar tingkat efisiensi penggunaan modal dalam memperoleh laba. Kinerja keuangan suatu perusahaan termasuk koperasi adalah menjadi sangat penting dan bersifat strategis dalam kaitannya terhadap kemajuan usaha.

Berdasarkan hasil obeservasi laporan keuangan Koperasi Tani desa Tejo masih dirasa kurang khususnya operasionalnya dimana banyak terjadi kredit macet. Anggota yang meminjam modal pada Koperasi Tani Makmur desa Tejo tidak memiliki kesadaran untuk mengembalikan modal yang dipinjam dikarenaka tidak adanya penahanan barang atau harta sebagai jaminan. Laporan tahunan Koperasi Tani Makmur desa Tejo masih banyak yang belum diperbaiki seperti daftar inventaris yang belum di 
up date. Rasio keuangan menunjukkan kinerja Koperasi Tani Makmur desa Tejo sangat baik namun pada kenyataan banyak terjadi kredit macet hal ini disebabkan banyak modal yang masih mengendap pada kas sehingga kegiatan koperasi dirasa kurang produktif.

\section{B. Tinjauan Pustaka \\ 1. Pengertian Koperasi}

Koperasi Indonesia menurut UU No.25/1995 tentang perkoperasian adalah badan usaha yang beranggotakan orang seorang atau badan hukum koperasi, dengan melandaskan kegiatan berdasarkan prinsip koperasi sekaligus sebagai gerakan ekonomi rakyat, yang berdasarkan asas kekeluargaan. Koperasi adalah badan hukum yang didirikan oleh orang perseorangan atau badan hukum Koperasi, dengan pemisahan kekayaan para anggotanya sebagai modal untuk menjalankan usaha, yang memenuhi aspirasi dan kebutuhan bersama di bidang ekonomi, sosial, dan budaya sesuai dengan nilai dan prinsip Koperasi (Pasal 1 UU No.17/2012).

Menurut pasal 4 UU No.17/2012 menjelaskan bahwa koperasi bertujuan meningkatkan kesejahteraan Anggota pada khususnya dan masyarakat pada umumnya, sekaligus sebagai bagian yang tidak terpisahkan dari tatanan perekonomian nasional yang demokratis dan berkeadilan. Hendrojogi (2012:22) menjelaskan bahwa koperasi adalah suatu perkumpulan dari orang-orang yang atas dasar persamaan derajat sebagai manusia, dengan tidak memandang haluan agama dan politik secara sukarela masuk, untuk sekedar memenuhi kebutuhan bersama yang bersifat kebendaan atas tanggungan bersama. Rudianto (2010:3) berpendapat bahwa koperasi adalah perkumpulan orang yang secara sukarela mempersatukan diri untuk berjuang meningkatkan kesejahteraan ekonomi mereka melalui pembentukan sebuah badan usaha yang dikelola secara demokratis.

\section{Nilai dan Prinsip Koperasi}

Menurut pasal 5 ayat 1 UU No.17/2012, Nilai yang mendasari kegiatan Koperasi yaitu kekeluargaan, menolong diri sendiri, bertanggung jawab, demokrasi, persamaan, berkeadilan, dan kemandirian. Lebih lanjut menurut pasal 5 ayat 2 UU No.17/2012, Nilai yang diyakini Anggota Koperasi yaitu kejujuran, keterbukaan, tanggung jawab, dankepedulian terhadap orang lain.

Menurut pasal 6 ayat 1 UU No.17/2012, Koperasi melaksanakan Prinsip Koperasi yang meliputi:

1. keanggotaan Koperasi bersifat sukarela dan terbuka

2. pengawasan oleh Anggota diselenggarakan secara demokratis

3. Anggota berpartisipasi aktif dalam kegiatan ekonomi Koperasi

4. Koperasi merupakan badan usaha swadaya yang otonom, dan independen

5. Koperasi menyelenggarakan pendidikan dan pelatihan bagi Anggota, Pengawas, Pengurus, dan karyawannya, serta memberikan informasi kepada masyarakat tentang jati diri, kegiatan, dan kemanfaatan Koperasi

6. Koperasi melayani anggotanya secara prima dan memperkuat Gerakan Koperasi, dengan bekerja sama melalui jaringan kegiatan pada tingkat lokal, nasional, regional, dan internasional

7. Koperasi bekerja untuk pembangunan berkelanjutan bagi lingkungan dan masyarakatnya melalui kebijakan yang disepakati oleh Anggota. 


\section{Jenis Koperasi}

Berdasarkan bidang usaha dan jenis anggotanya, koperasi dapat dikelompokkan ke dalam 4 jenis.Bidang usaha koperasi mencerminkan jenis produk yang dijual kepada masyarakat dan para anggotanya. Berdasarkan pasal 83 UU No. 17/2012 jenis koperasi terdiri dari empat jenis, yaitu:

1. Koperasi Konsumen. Koperasi konsumen adalah koperasi yang anggotanya terdiri dari para konsumen akhir atau pemakai barang atau jasa. Kegiatan utama koperasi konsumen adalah melakukan pembelian bersama. Jenis barang atau jasa yang dilayani suatu koperasi konsumen sangat tergantung pada latar belakang kebutuhan anggota yang akan dipenuhi. Sebagai contoh, koperasi yang mengelola took serba ada, mini market, dan sebagainya.

2. Koperasi Produsen. Koperasi produsen adalah koperasi yang para anggotanya tidak memiliki badan usaha sendiri tetapi bekerja sama dalam wadah koperasi untuk menghasilkan dan memasarkan barang atau jasa. Kegiatan utama koperasi produsen adalah menyediakan, mengoperasikan dan mengelola sarana produksi bersama. Tujuan utama koperasi produsen adalah menyatukan kemampuan dan modal para anggotanya guna menghasilkan barang-barang atau jasa tertentu melalui suatu badan usaha yang mereka kelola dan miliki sendiri

3. Koperasi Jasa. Koperasi jasa menyelenggarakan kegiatan usaha pelayanan jasa nonsimpan pinjam yang diperlukan oleh Anggota dan non-Anggota.

4. Koperasi Simpan Pinjam. Koperasi kredit atau koperasi simpan pinjam adalah koperasi yang bergerak dalam bidang pemupukan simpanan dana dari para anggotanya, untuk kemudian dipinjamkan kembali kepada para anggota yang memerlukan bantuan dana. Kegiatan utama koperasi simpan pinjam adalah menyediakan jasa penyimpanan dan peminjaman dana kepada anggota koperasi.

\section{Pengertian Kredit}

Kredit berasal dari bahasa Yunani "Credere" yang berarti kepercayaan, oleh karena itu dasar dari kredit adalah kepercayaan. Seseorang atau semua badan yang memberikan kredit (kreditur) percaya bahwa penerima kredit (debitur) di masa mendatang akan sanggup memenuhi segala sesuatu yang telah dijanjikan itu dapat berupa barang, uang atau jasa (Thomas, dkk, 2010:12).

Kredit adalah penyediaan uang atau tagihan yang dapat dipersamakan dengan itu, berdasarkan persetujuan atau kesepakatan pinjam meminjam antara bank dengan pihak lain yang mewajibkan pihak peminjam untuk melunasi utangnya setelah jangka waktu tertentu dengan pemberian bunga (Undang-Undang Nomor 10 Tahun 1998, pasal 21 ayat 11). Taswan (2009:163) menjelaskan bahwa kredit yang diberikan oleh bank dapat didefinisikan sebagai penyediaan uang atau tagihan yang dapat dipersamakan dengan itu, berdasarkan persetujuan atau kesepakatan pinjam-meminjam antara bank dengan pihak lain yang mewajibkan pihak peminjam untuk melunasi hutangnya setelah jangka waktu tertentu dengan jumlah bunga, imbalan atau pembagian hasil keuntungan.

\section{Unsur-unsur Kredit}

Kasmir (2012:87) menjelaskan bahwa unsur-unsur dalam pemberian kredit adalah sebagai berikut:

a. Kepercayaan. Kepercyaan adalah suatu keyakinan pemberi kredit bahwa kredit yang diberikan baik berupa uang, barang atau jasa akan benar-benar diterima kembali dimasa yang akan datang. Kepercayaan ini diberikan oleh bank, karena sebelum dana dikucurkan sudah dilakukan penelitian dan penyelidikan yang mendalam tentang 
nasabah. Penelitian dan penyelidikan dilakukan untuk mengetahui kemampuan dalam melunasi kredit yang disalurkan

b. Kesepakatan. Disamping unsur kepercayaan, di dalam kredit juga mengandung unsur kesepakatan antara debitur dan kreditur. Kesepakatan ini dituangkan dalam suatu perjanjian dimana masing-masing pihak menandatangani hak dan kewajibannya masing-masing. Kesepakatan penyaluran kredit dituangkan dalam akad kredit yang ditangani oleh kedua belah pihak, yaitu pihak bank dan nasabah.

c. Jangka waktu. Setiap kredit yang diberikan pasti memiliki jangka waktu tertentu, jangka waktu ini mencakup masa pengembalian kredit yang telah disepakati. Hampir dapat dipastikan bahwa tidak ada kredit yang tidak memiliki jangka waktu.

d. Risiko. Faktor risiko kerugian dapat diakibatkan dua hal, yaitu: resiko kerugian yang diakibatkan debitur sengaja tidak mau membayar kreditnya pada hal mampu dan resiko kerugian yang diakibatkan karena debitur tidak sengaja yaitu akibat terjadinya musibah seperti bencana alam. Penyebab tidak tertagih sebenarnya dikarenakan adanya suatu tenggang waktu pengembalian (jangka waktu). Semakin panjang jangka waktu suatu kredit, semakin besar risiko tidak tertagih, demikian pula sebaliknya. Risiko ini menjadi tanggungan bank baik risiko yang disengaja maupun risiko yang tidak disengaja

e. Balas jasa. Akibat dari pemberian fasilitas kredit bank tentu mengharapkan suatu keuntungan dalam jumlah tertentu. Keuntungan atas pemberian suatu kredit barang atau jasa tersebut yang dikenal dengan bunga bagi bank prinsip konvensional. Balas jasa dalam bentuk bunga, biaya provisi dan komisi serta biaya administrasi kredit ini merupakan keuntungan utama bank.

\section{Metode}

Metode yang digunakan pada pendapingan ini dengan informan yang digunakan sebanyak 4 orang yang terdiri dari kepala desa, ketua Koperasi Tani Sejahtera, sekretaris dan bendahara Koperasi Tani Sejahtera. Adapun metode yang digunakan dalam pengabdian ini yang adalah sebagai berikut:

1. Kegiatan penyuluhan pentingnya pembuatan laporan tahunan dan manajemen operasional pemberian kredit yang dilakukan dengan sesi Tanya jawab terhadap kepala desa.

2. Tahap pelaksanaan dimana dilaksanakan kegiatan penyuluhan pebimbing melakukan analisa dari dokumen yang disediakan berupa laporan tahunan Koperasi Tani Sejahtera kemudian memberikan arahan bagaimana penyusunan laporan tahunan Koperasi Tani Sejahtera yang efektif dan mudah dibaca serta bagaimana manajemen operasional kredit agar tidak banyak kredit macet.

3. Tahapan Monitoring dan Evaluasi dimana dilakukan analisa hasil pembuatan laporan tahunan setelah dilakukan pendampingan dengan sebelum dilakukan pendampingan, serta operasional kredit setelah dilakukan pendampingan dengan sebelum dilakukan pendampingan.

\section{Hasil Dan Pembahasan}

Desa Tejo Kecamatan Mojoagung terletak di koordinat 112.310859 LS/LU 7.569782 BT/BB, dengan batas wilayah sebelah utara Desa Palrejo, sebelah selatan Desa Sukomulyo, sebelah timur Desa Gambiran dan Sebelah barat Desa Sawahan. Luas wilayah 349 Ha dan luas tanah kas desa19 Ha. Daftar Mata pencaharian masyarakat 
Desa Tejo dari sektor pertanian 512 orang, 4 orang pemilik usaha tani, 621 orang buruh tani.

Sama halnya dengan desa pada umumnya, Desa Tejo kecamatan Mojoagung mempunyai kegiatan usaha dibidang perkredita atau simpan pinjam. Koperasi Tani Makmur yang bergerak dalam unit simpan pinjam, diperlukan modal yang cukup dengan pengelolaan yang baik.

Pendampingan awal dilakukan dengan menunjukkan laporan keuangan tahun sebelumnya dimana laporan keuangan tahunan sudah dibuat lebih rapi, namun masih terdapat kekurangan-kekurangan dalam pembuatan laporan tahunan diantaranya Laporan tahunan Koperasi Tani Makmur desa Tejo masih banyak yang belum diperbaiki seperti daftar inventaris yang belum di diperbarui. Hal ini lazim dialami oleh beberapa lembaga keuangan yang dimiliki desa yang mengalami kesulitan dalam penyusunan laporan keuangan sesuai dengan standar akuntansi )Mutiarni, R., Utomo, L. P., \& Zuhroh, S, 2017)

Dilihat dari rasio keuangan tercatat bahwa kinerja Koperasi Tani Makmur desa Tejo sangat baik namun pada kenyataan banyak terjadi kredit macet hal ini disebabkan banyak modal yang masih mengendap pada kas sehingga kegiatan koperasi dirasa kurang produktif. Pendampingan selanjutnya dilakukan dengan pemberian materi dan arahan bagaimana penyusunan laporan keuangan tahunan yang sistematik dan secara komputer menggunakan Ms. Excel karena akan mempermudah pekerjaan (Mutiarni, R, 2017) Adapun fokus penyusunan laporan neraca, neraca komparatif, perhitungan hasil usaha, perhitungan sisa hasil usaha, inventarisasi, simpanan anggota, rencana kerja, laporan hasil pemeriksaan pengawas dan analisa keuangan.
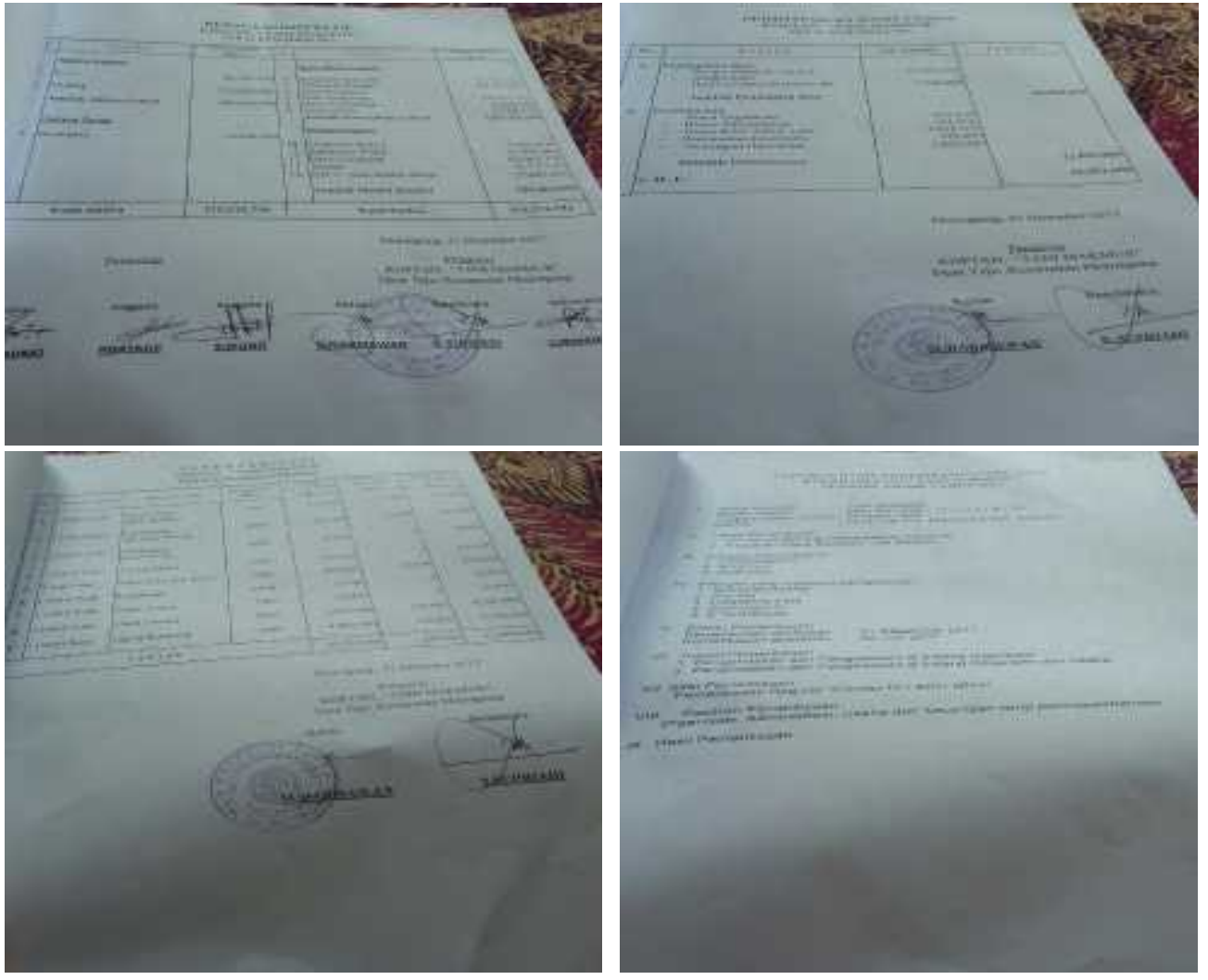

Gambar 1. Laporan Keuangan Koperasi Tani Makmur Desa Tejo 
Selanjutnya pemberian pengarahan tentang manajemen operasional penyaluran kredit dimana kredit yang disalurkan oleh Koperasi Tani Makmur desa Tejo mengalami kemacetan. Kemacetan ini disebabkan karena tidak adanya jaminan yang diberikan dalam penyaluran kredit. Untuk itu perlu adanya manajemen operasional yang baik dimana dalam pemberian pengarahan peserta diharapkan dapat mengubah manajemen operasional penyaluran kredit dengan pemberian jaminan berupa kartu keluarga asli atau ijasah. Disisi lain perlu untuk melakukan cross chek dengan bagian koperasi lain seperti koperasi wanita dan BKD apakah debitur tersebut masih mempunyai tanggungan kredit pada unit usaha lain di Desa Tejo.

Hasil kegiatan pelatihan dan pendampingan yang dilakukan selama 4 hari format laporan keuangan dan manajemen operasional penyaluran kredit perlahan telah diperbaiki sehingga operasional kredit Koperasi Tani Makmur desa Tejo dapat berjalan dengan aman, terpercaya dan tertib.

\section{E. Penutup}

Dari hasil pengamatan pendampingan laporan keuangan Koperasi Tani Makmur desa Tejo dilaksanakan sesuai dengan apa yang diharapkan. Hal ini dapat dilihat dari respon positif dari kepala desa, ketua, sekretaris dan bendahara yang mau untuk berbagi dan memperbaiki kualitas laporan keuangan serta manajemen operasional kredit pada Koperasi Tani Makmur desa Tejo. Selanjutnya diharapkan kegiatan pendampingan untuk pembuatan laporan keuangan serta arahan manajemen operasional penyaluran kredit pada koperasi-koperasi desa lain dapat dilaksanakan sehingga seluruh koperasi dapat berjalan dengan produktif dan sistematis.

\section{DAFTAR PUSTAKA}

, Peraturan Pemerintah Nomor 60 tahun 1959

, Undang-undang Nomor 10 Tahun 1998 tentang Perubahan Atas UndangUndang Nomor 7 Tahun 1992 tentang Perbankan

, Undang-Undang Republik Indonesia Nomor 17 Tahun 2012 tentang perkoperasian

, Undang-undang Republik Indonesia Nomor 25 Tahun 1992 Tentang Perkoperasian

Hendrojogi. 2012. Koperasi: Azas-azas Teori dan Praktek. Jakarta: PT. Raja Grafindo Persada

Kasmir. 2012. Dasar- Dasar Perbankan. Jakarta: PT. Raja Grafindo Persada

Mahri, A. Jajang W. Pelayanan dan Manfaat Koperasi, serta Pengaruhnya terhadap Partisipasi Anggota: Suatu Kasus pada Koperasi Produsen Tahu Tempe Kabupaten Tasikmalaya. Universitas Pendidikan Indonesia.

Rudianto. 2010. Akuntansi Koperasi. Jakarta: Erlangga. 
Taswan. 2009. Manajemen Perbankan, Konsep, Teknik, dan Aplikasi. Yogyakarta: UPP STIM YKPN

Thomas, Suyatno, Dkk. 2010. Kelembagan Perbankan. Jakarta: PT. Gramedia Pustaka Utama

Mutiarni, R., Utomo, L. P., \& Zuhroh, S. (2017). Pendampingan Pencatatan Transaksi Keuangan Pada Koperasi Bunga Harapan Desa Ceweng. Comvice: Journal Of Community Service, 1(1), 33-38.

Mutiarni, R. (2017). Implementasi Electronic Data Processing Pada Koperasi Wanita. Eksis: Jurnal Riset Ekonomi dan Bisnis, 12(2 Okt), 135-148. 